\title{
HUBUNGAN FAKTOR SOSIODEMOGRAFI DENGAN STATUS GIZI PADA SISWA DI SDN CIASMARA 05 KECAMATAN PAMIJAHAN KABUPATEN BOGOR TAHUN 2018
}

\author{
Nur Jubaidah Adawiah ${ }^{1)}$, Ichayuen Avianty ${ }^{2)}$, Merry Maeta Sari ${ }^{3)}$ \\ ${ }^{1)}$ Konsentrasi Kesehatan Ibu dan Anak, Program Studi Kesehatan Masyarakat, Fakultas Ilmu Kesehatan Universitas Ibn \\ Khaldun Bogor \\ Email: njubaidah06@gmail.com \\ ${ }^{2)}$ Program Studi Kesehatan Masyarakat, Fakultas Ilmu Kesehatan Universitas Ibn Khaldun Bogor \\ Email: ichayuen@gmail.com \\ ${ }^{3)}$ Program Studi Kesehatan Masyarakat, Fakultas Ilmu Kesehatan Universitas Ibn Khaldun Bogor \\ Email: meta_ssi@yahoo.co.id
}

\begin{abstract}
Abstrak
Gizi memiliki peranan penting mempertahankan kesehatan anak. Prevalensi anak kurus di Indonesia sebesar 10,5\%. Pada Provinsi Jawa Barat status gizi anak Kabupaten Bogor lebih rendah dibandingkan status gizi anak di Kota Bogor. Status gizi sendiri dapat dipengaruhi oleh beberapa hal, salah satunya adalah status demografi. Tujuan penelitian ini adalah diketahuinya observasionel analitik dengan pendekatan cross-sectional. Populasi yaitu siswa-siswi SD Ciasmara 05 Kecamatan Pamijahan Kabupaten Bogor, dengan besar sampel 120 orang. Uji statistik digunakan uji chi-square. Hasil analisis uivariat diperoleh status gizi normal (70,2\%), umur 6-9 tahun (55,0\%), berjenis kelamin laki-laki $(61,7 \%)$, ibu berpendidikan tinggi $(74,2 \%)$, pekerjaan ayah adalah buruh $(50,8 \%)$, orang tua memiliki pendapatan $\operatorname{rendah}(<\mathrm{Rp} .2 .975 .000)(53,3 \%)$. Hasil analisis bivariat diperoleh adanya hubungan antara tingkat pendidikam ibu $(p$-value $=0,000)$ dan status pekerjaan ayah $(p$-value $=0,022)$ dengan status gizi anak. Sedangkan tidak ada hubungan antara penghasilan keluarga ( $p$-value $=0,123)$, umur $(p$-value $=0,190)$ dan jenis kelamin $(p$-value $=0,973)$ dengan status gizi pada anak. Diharapkan pihak sekolah dapat berkoordinasi dengan petugas kesehatan dalam melakukan pengawasan terhadap status gizi anak didiknya.
\end{abstract}

Kata Kunci : Sosiodemografi, status gizi anak.

\section{PENDAHULUAN}

Indonesia dan negara-negara lain di dunia sedang mengalami masalah yang sama yakni masalah gizi. Anak-anak merupakan penderita masalah gizi terbesar. Dilihat dari segi wilayah, lebih dari $70 \%$ kasus masalah gizi pada anak didominasi Asia, sedangkan 26\% di Afrika dan 4\% di Amerika Latin serta Karibia. Food and Agricultire Organization (FAO) memperkirakan sekitar 870 juta orang dari 7,1 miliar penduduk dunia atau 1 dari 8 orang penduduk dunia menderita masalah gizi. Sebanyak 852 juta di antaranya tinggal di negara-negara berkembang salah satunya adalah di Indonesia (National Geographic Indonesia, 2015).

Gizi merupakan faktor utama yang mendukung terjadinya proses metabolisme di dalam tubuh. Setiap reaksi kimia yang terjadi 
di dalam tubuh membutuhkan zat gizi tertentu untuk pelaksanaannya (Fikawati dkk, 2017).

Menurut Word Health Organization (WHO) suatu wilayah atau negara di katakan kategori baik dalam hal status gizi apabila prevalensi kejadian status gizi anak kurus kurang dari 5\%, sedangkan Hasil Pemantauan Status Gizi (PSG, 2016) menunjukan bahwa prevalensi anak dengan status gizi kurus usia 6-12 tahun 2016 di Indonesia mencapai 10,5\%. Ini menunjukan bahwa masalah gizi di Indonesia menduduki posisi akut.

Kejadian anak dengan status gizi anak kurus terendah terdapat di provinsi Bali mencapai $5,5 \%$ dan provinsi terbanyak terdapat di provinsi NTT yakni 22,4\%. Sedangkan di Jawa Barat prevalensi anak dengan status gizi kurus mencapai 7,3\% (PSG, 2016). Pada Provinsi Jawa Barat prevalensi anak dengan status gizi normal di daerah pedesaan lebih rendah dibandingan dengan daerah perkotaan. Menurut Riset Kesehatan Dasar (RISKESDAS) prevalensi status gizi anak berdasarkan indeks masa tubuh per umur (IMT/U) Kabupaten Bogor tercacat memiliki anak dengan status gizi normal lebih rendah yaitu $75,1 \%$ di bandingkan dengan kota Bogor sebanyak 77,5\%.

Masalah gizi pada hakikatnya adalah masalah kesehatan masyarakat, namun penanggulangannya tidak dapat di lakukan dengan pendekatan medis dan pelayanan kesehatan saja. Penyebab timbulnya masalah gizi adalah multifaktor, oleh karena itu pendekatan penanggulangan harus melibatkan sektor yang terkait (Supariasa et al., 2002).

Status gizi sendiri dapat dipengaruhi oleh beberapa hal, salah satunya adalah status demografi yang meliputi jenis kelamin, umur, pendapatan keluarga, pekerjaan ayah serta tingkat pendidikan ibu. Perbedaan jenis kelamin memberikan pengaruh dalam distribusi lemak subkutan dan masa otot. Sehingga akan timbul perbedaan status gizi antara laki-laki dan perempuan. Sedangkan umur memiliki peranan penting dimana setiap umur memiliki tingkatan maturitas sel-sel pencernaan yang berbeda sehingga dapat mempengaruhi status gizi seseorang. Tingkat pendidikan ibu pun juga mempengaruhi, dimana ibu dengan pendidikan tinggi cenderung memilih makanan bergizi dibandingkan dengan ibu yang memiliki tingkat pendidikan rendah. Pemenuhan kebutuhan gizi melalui karakteristik sosioekonomi berupa pendapatan dan pekerjaan juga mempengaruhi. Hal tersebut terlihat dimana apabila pemenuhan kebutuhan semakin tinggi maka status gizi anak pun juga semakin baik (Djola, 2012; Saputri 2010).

Pekerjaan kepala keluarga atau ayah dan pendidikan ibu berhubungan dengan status gizi anak pada anak usia 6-12 tahun (Salimar, dkk., 2013) . Anisa (2012) dalam penelitiannya menyatakan adanya hubungan bermakna antara pendidikan orang tua, pekerjaan ayah, dan status ekonomi dengan statatus gizi anak. Hasil analisis bivariat yang telah di laksanakan oleh Arlovi (2016) menyatakan adanya hubungan tingkat pendapatan keluarga dengan status gizi anak.

Menurut Profil Kesehatan Kabupaten Bogor tahun 2015 Kecamatan Pamijahan memiliki pendapatan penduduk yang rendah yaitu $11,15 \%$ dibandingkan dengan kecamatan Dramaga 92,82\% dan Kecamatan Ciomas 40,85\%.

Dinas Pendidikan Kabupaten Bogor menyatakan SD Negeri Ciasmara 05 merupakan SD Negeri paling terpencil di kecamatan Pamijahan, mayoritas penduduk memiliki mata pencarian sebagai petani karena keadaan demografis pegunungan dan merupakan perbatasan antara Kabupaten Bogor dengan Sukabumi.

Berdasarkan hal tersebut, peneliti tertarik untuk meneliti hubungan faktor sosiodemografi dengan status gizi anak di 
SDN Ciasmara 05 Kecamatan Pamijahan Kabupaten Bogor.

\section{METODE}

Penelitian ini dilakukan dengan menggunakan observasional analitik atau kuantitatif dengan pendekatan cross- sectional yaitu penelitian yang dilakukan satu kali, dalam satu waktu yang digunakan untuk menilai suatu hubungan antara variabel terikat dengan variabel bebas.

Penelitian ini dilakukan di SDN Ciasmara 05 yang berada di Kecamatan Pamijahan Kabupaten Bogor. Sedangkan waktu penelitian dilaksanakan pada bulan Juli sampai Agustus 2018 yang dimulai dari observasi sampai pengambilan data.

Populasi dalam penelitian ini adalah semua siswa yg berada di SDN Ciasmara 05 Kecamatan Pamijahan Kabupaten Bogor. Sampel yang digunakan dalam penelitian ini adalah 120 orang dari 140 orang yang telah di

\section{HASIL}

Data yang diperoleh dianalisa melalui komputer dengan menggunakan program Statistic Package for Sosial Science (SPSS) versi 19. Berikut hasil pengelolaan data penelitian. Berdasarkan hasil analisis univariat diperoleh status gizi anak di SDN Ciasmara 05 Kecamatan Pamijahan Kabupaten Bogor di bagi menjadi tiga kategori yaitu nomal, kurus dan gemuk, namun setelah di lakukan penelitian status gizi di SDN Ciasmara 05 Kecamatan Pamijahan Kabupaten Bogor hanya memiliki 2 kategori yaitu normal $(70,8 \%)$ dan kurus $(29,2 \%)$. Berdasarkan faktor umur anak usia, rata-rata anak berumur 6-9 tahun $(66,0 \%)$ dan10-13 tahun $(45,0 \%)$. Berdasakan faktor jenis kelamin mayoritas adalah laki laki $(61,7 \%)$ sedangkan perempuan hanya $38,8 \%$. Berdasarkan faktor pendidikan hitung menggunakan tekhnik proporsional startifed randim sampling. Variabel independen atau variabel bebas dari penelitian ini adalah umur, jenis kelamin, pendidikan ibu, pekerjaan ayah dan penghasilan keluarga. Variabel dependen atau variabel terkait dalam penelitian ini adalah status gizi anak.

Data yang digunakan dalam penelitian ini ada 2 macam yaitu data primer dan data sekunder. Data primer dalam penelitian ini adalah data yang di ambil dari siswa-siswi SDN Ciasmara 05 Kecamatan Pamijahan Kabupaten Bogor dengan mengukur berat badan dan tinggi badan anak, data sekunder dalam penelitian ini adalah data yang di ambil dari data yang ada di sekolah yaitu jumlah siswa yang berada di SDN Ciasmara 05 Kecamatan Pamijahan Kabupaten Bogor.

ibu, ibu dengan pendidikan tinggi lebih banyak (74,2\%) dibadingkan dengan ibu berpendidikan rendah $(25,8 \%)$ Berdsarkan faktor pekerjaan ayah dengan bekerja sebagai buruh $(50,8 \%)$ dan petani 49,2\%). Berdasarkan faktor penghasilan keluarga, dengan penghasilan tinggi $\geq$ UMP Kabupaten Bogor sebanyak 53,3\% dan rendah $\leq$ UMP Kabupaten Bogor sebanyak 46,7\%.

Dari hasil analisis bivariat (chi-square) 1 - 5 dapat diketahui bahwa variabel yang memiliki hubungan yang signifikan dengan status gizi anak adalah pendidikan ibu ( $p$-value $0,000)$ dan pekerjaan ayah ( $p$-value 0,0220 ). Sedangkan variabel yang tidak berhubungan dengan status gizi anak adalah umur ( $p$-value $0,190)$, jenis kelamin ( $p$-value 0,973) dan penghasilan keluarga ( $p$-value 0,123$)$. 
Tabel 1. Hubungan Umur dengan Status Gizi Anak di SDN Ciasmara 05 Kecamatan Pamijahan Kabupaten Bogor

\begin{tabular}{ccccccccc}
\hline Umur & \multicolumn{4}{c}{ Status Gizi Anak } & Total & & P-Value & OR (95\% \\
& Normal & \multicolumn{2}{c}{ Kurus } & & & & CI) \\
& n & \% & n & \% & n & \% & & \\
\hline 6-9 tahun & 43 & 65,2 & 23 & 34,8 & 66 & 100,0 & 0,190 & 0,534 \\
10-13 tahun & 42 & 77,8 & 12 & 22,2 & 54 & 100,0 & & $(0,236-$ \\
Jumlah & 85 & 70,8 & 35 & 29,2 & 120 & 100,0 & & $1,210)$ \\
\hline
\end{tabular}

Tabel 2. Hubungan Jenis Kelamin dengan Status Gizi Anak di SDN Ciasmara 05 Kecamatan Pamijahan Kabupaten Bogor

\begin{tabular}{ccccccccc}
\hline Jenis & \multicolumn{4}{c}{ Status Gizi Anak } & Total & & P-Value & OR (95\% \\
Kelamin & Normal & \multicolumn{2}{c}{ Kurus } & & & & CI) \\
& n & \% & n & \% & n & \% & & \\
\hline Perempuan & 32 & 69,6 & 14 & 30,4 & 46 & 100,0 & 0,973 & 0,906 \\
Laki-laki & 53 & 71,6 & 21 & 28,4 & 74 & 100,0 & & $(0,404-$ \\
Jumlah & 85 & 70,8 & 35 & 29,2 & 120 & 100,0 & & $2,028)$ \\
\hline
\end{tabular}

Tabel 3. Hubungan Pendidikan Ibu dengan Status Gizi Anak di SDN Ciasmara 05 Kecamatan Pamijahan Kabupaten Bogor

\begin{tabular}{ccccccccc}
\hline $\begin{array}{c}\text { Pendidikan } \\
\text { Ibu }\end{array}$ & \multicolumn{4}{c}{ Status Gizi Anak } & Total & & P-Value & OR (95\% \\
& Normal & \multicolumn{2}{c}{ Kurus } & & & & CI) \\
& n & \% & n & \% & n & \% & & 7,224 \\
Rendah & 12 & 22,0 & 19 & 61,3 & 31 & 100,0 & 0,000 & $(2,929-$ \\
Tinggi & 73 & 82,0 & 16 & 26,0 & 89 & 100,00 & & $17,818)$ \\
Jumlah & 85 & 70,8 & 35 & 29,2 & 120 & 100,0 & \\
\hline
\end{tabular}

Tabel 4. Hubungan Pekerjaan Ayah dengan Status Gizi Anak di SDN Ciasmara 05 Kecamatan Pamijahan Kabupaten Bogor

\begin{tabular}{ccccccccc}
\hline $\begin{array}{c}\text { Pekerjaan } \\
\text { Ayah }\end{array}$ & \multicolumn{4}{c}{ Status Gizi Anak } & Total & & P-Value & OR (95\% \\
& Normal & \multicolumn{2}{c}{ Kurus } & & & & CI) \\
& n & $\%$ & n & \% & n & \% & \\
\hline Buruh & 37 & 60,7 & 24 & 39,9 & 61 & 100,0 & 0,0220 & 0,353 \\
Petani & 48 & 81,4 & 11 & 18,6 & 59 & 100,0 & & $(0,154-$ \\
Jumlah & 85 & 79,8 & 35 & 29,2 & 120 & 100,0 & & $0,812)$ \\
\hline
\end{tabular}

Tabel 5. Hubungan Penghasilan Keluarga dengan Status Gizi Anak di SDN Ciasmara 05 Kecamatan Pamijahan Kabupaten Bogor

\begin{tabular}{lcccccccc}
\hline $\begin{array}{l}\text { Pendapatan } \\
\text { Keluarga }\end{array}$ & \multicolumn{4}{c}{ Status Gizi Anak } & Total & & P-Value & OR (95\% \\
& Normal & \multicolumn{2}{c}{ Kurus } & & & & CI) \\
& n & \% & n & \% & n & \% & \\
\hline Rendah & 41 & 64,1 & 23 & 35,9 & 64 & 100,0 & 0,123 & 0,486 \\
Tinggi & 44 & 78,6 & 12 & 21,4 & 56 & 100,0 & & $(0,215-$ \\
Jumlah & 85 & 70,8 & 35 & 29,2 & 120 & 100,0 & & $1.101)$ \\
\hline
\end{tabular}




\section{PEMBAHASAN}

Berdasarkan tabel 1, diperoleh bahwa hasil penelitian ini tidak terdapat hubungan antara umur dengan status gizi anak karena umur merupakan jumlah tahun yang dilalui seseorang dari lahir hingga ulang tahun terakhir. Hasil penelitian ini sejalan dengan penelitian Arlovi (2016), menyatakan bahwa tidak ada hubungan antara umur dengan status gizi anak. Namun hasil ini tidak sejalan dengan penelitian Hakim (2016) yang menyatakan bahwa ada hubungan antara umur dengan status gizi anak.

Berdasarkan tabel 2, penelitian ini tidak terdapat hubungan antara jenis kelamin dengan status gizi anak karena jenis kelamin seseorang tidak bisa di prediksi berat badan seseorang saat lahir apakah kurus, normal atau gemuk. Sesuai dengan penelitian Taraigan (2013) jenis kelamin bukan merupakan faktor yang berhubungan dengan status gizi karena jenis kelamin hanya sebagai pembeda jenis dan tiap jenis memiliki masing-masing standar gizi. Demikian juga hasil penelitian Pritasari (2015) menyatakan tidak ada perbedaan antara status gizi balita berdasarkan jenis kelamin.

Berdasarken tabel 3, penelitian ini terdapat hubungan yang signifikan antara pendidikan ibu dengan status gizi anak karena tingkat pendidikan ibu berkaitan erat dengan kesadaran kesehatan terutama konsumsi makanan untuk anak dan keluarga. Tinggi rendahnya pendidikan terakhir yang diikuti oleh ibu setelah lulus dan memiliki anak memperlihatkan besarnya perhatian terhadap makanan yang di konsumsi dengan kebuthan tubuh anak. Temuan ini sejalan dengan hasil penelitian Arlovi (2016) dan penelitian Revan (2015) yang menunjukan adanya hubungan antara pendidikan ibu dengan status gizi anak. Pada anak dengan ibu pendidikan rendah memiliki status gizi kurang karena rendahnya kesadaran mengenai kesehatan sehingga mengakibatkan kurang perhatian terhadap asupan makanan yang di konsumsi oleh anaknya dan hanya mengkonsumsi makanan yang diinginkan tanpa memperhatikan gizi yang terkandung. Sedangkan pada anak dengan ibu pendidikan tinggi memiliki status gizi normal karena memiliki tingkat kesadaran yang lebih dari anak dengan pendidikan ibu rendah hanya dalam mengkonsumsi makanan sangat mempertimbangkan gizi yang terkandung dalam makanan yang dikonsumsi.

Berdasarkan tabel 4, Hasil analisis hubungan antara pekerjaan ayah dengan status gizi anak di peroleh 61 responden dengan pekerjaan ayah sebagai buruh dimana 37 atau $60,7 \%$ responden memiliki anak dengan status gizi normal, sedangkan 24 atau 39,9\% responden memiliki anak dengan status gizi kurus. Dan sebanyak 59 responden dengan pekerjaan ayah sebagai petani dimana 48 atau $81 \%$ responden memiliki anak dengan status gizi normal, sedangkan 11 atau $18,6 \%$ responden memiliki anak dengan status gizi kurus. Hasil ini menunjkan bahwa kecenderungan pekerjaan orang tua kategori petani memiliki status gizi anak lebih tinggi dibandingkan dengan kategori buruh hal tersebut dikarenakan petani memiliki sumber bahan makanan sendiri sehingga sumber bahan makanan dengan kualitas terbaik akan di utamakan untuk keluarganya sebelum menjualnya. Hasil penelitian ini sejalan dengan Herawati (2013) dan Al Ghazali (2013) yang menyatakan adanya hubungan status gizi anak dengan pekerjaan ayah.

Beradarkan tabel 5, tidak terdapat hubungan antara pendapatan keluarag dengan status gizi anak. Umumnya, jika tingkat pendapatan keluarga naik, maka jumlah dan jenis makanan cenderung ikut membaik juga. Akan tetapi, mutu makanan tidak selalu membaik juga. Akan tetapi, mutu makanan tidak selalu membaik jika di terapkam tanaman pedagangan. Tanaman perdagangan 
menggantikan produksi pangan untuk rumah tangga dan pendapatan yang diperoleh dari tanaman perdagangan itu atau upaya peningkatan pendapatan yang lain tidak di canangkan untuk membeli pangan atau buahbuahan pangan yang berkualitas gizi tinggi. (Suhardjo, 2003). Ahli ekonomi berpendapat bahwa dengan perbaikan taraf ekonomi maka tingkat gizi pendukung akan meningkat. Namun ahli gizi dapat menerima dengan catatan, bukan hanya faktor ekonomi saja yang merupakan penentu status gizi, kenyatannya masalah gizi bersifat multikompeks karena tidak hanya faktor ekonomi yang berperan

\section{KESIMPULAN}

Berdasarkan hasil penelitian di yang dilakukan terhadap 120 siswa di SDN Ciasmara 05 Kecamatan Pamijahan Kabupaten Bogor di peroleh bahwa 85 responden atau $70,8 \%$ memiliki status gizi normal. Proporsi terbanyak pada kelompok umur 6-9 tahun yaitu 66 responden atau 55,0\%, reponden dengan jenis kelamin laki-laki menjadi proporsi terbanyak yaitu 74 responden atau $61,7 \%$ yang memiliki status gizi normal. Proporsi responden yang memiliki ibu dengan pendidikan tinggi lebih banyak yaitu 89 responden atau 74,2\% dengan responden ibu dengan pendidikan rendah yaitu 31 responden atau 25,8\%. Proposri terbanyak responden memiliki ayah bekerja sebagai buruh 61 responden atau 50,8\% dan petani 59 responden atau $49,2 \%$, sedangkan penghasilan keluarga prosporsi terbanyak memiliki penghasilan rendah yaitu 64 responden atau 53,3\%. Jadi dari hasil penelitian ini tidak semua faktorfaktor yang di teliti menggunakan teori Unicef tetapi faktor-faktor lain ikut menentukan. Oleh karena itu perbaikan gizi dapat dianggap sebagai alat maupun sebagai sasaran dari pada pembangunan. (Suhardjo, 2003). Hasil penelitian ini tidak sejalan dengan hasil penelitian Arlovi (2016) dan penelitian Ismail (2013) yang menyatakan adanya hubungan antara status gizi dengan pendapatan keluarga. Karena bukan hanya faktor ekonomi saja yang merupakan penentu status gizi, kenyatannya masalah gizi bersifat multikompeks karena tidak hanya faktor ekonomi yang berperan tetapi faktor-faktor lain ikut menentukan.

(1998) mempunyai hubungan yang signifikan dengan status gizi di SDN Ciasmara 05 Kecamatan Pamijahan Kabupaten Bogor.

Faktor yang memiliki hubungan dengan status gizi anak di SDN Ciasmara 05 Kecamatan Pamijahan Kabupaten Bogor yaitu pendidikan ibu ( $p$-value 0,000$)$ dan pekerjaan ayah (p-value 0,0220) karena tingkat pendidikan ibu berkaitan erat dengan kesadaran kesehatan terutama konsumsi makanan untuk anak dan keluarga, dan pekerjaan ayah dikarenakan petani memiliki sumber bahan makanan sendiri sehingga sumber bahan makanan dengan kualitas terbaik akan di utamakan untuk keluarganya sebelum menjualnya. Sedangkan tidak terdapat hubungan antara faktor umur ( $p$-value 0,190), jenis kelamin (p-value 0,973) dan pendapatan keluarga ( $p$-value 0,123) dengan status gizi anak di SDN Ciasmara 05 Kecamatan Pamijahan Kabupaten Bogor. 


\section{DAFTAR PUSTAKA}

[1] Abran Ardiansul, dkk. 2015. Hubungan Gaya Hidup Dengan Status Gizi Pada Anak Usia 6-12 Tahun Di Sekolah Dasar Negeri (SDN) Inpres Lesabe Kecamatan Tabukan Selatan Kabupaten Kepulauan Sanghie. Ejournal Keperawatan Vol.3 No. 2

[2] Ahmad Fariza. 2013. Hubungan Status Gizi Dengan Tingkat Sosial Ekonomi Orang Tua / Wali Murid Siswa Kelas Atas Sekolah Dasar Negeri 3 Jatiluhur Kecamatan Karanganyar Kabupaten Kebumen (Skripsi). Yogyakarta : Universitas Negeri Yogyakarta

[3] Amatseir, S. 2009. Prinsip Dasar Ilmu Gizi. Jakarta: PT Gramedia Pusaka Utama

[4] Andriani Elisa Pahlevi. (2012). Determinan Status Gizi Pada Siswa Sekolah Dasar. Jurnal Kesehatan (https://journal.unnes.ac.id/artikel_nju/k emas/2807 Diakses pada 5 Juli 2018)

[5] Apriliyanti Rina Fransiska. 2016. Perbedaan Status Gizi Anak Usia 6-12 Tahun Yang Tinggal Di Panti Asuhan dan Yang Tinggal Dengan Orang Tua (Skripsi). Surabaya: Universitas Katolik Widya Mandala

[6] Arlovi, Isnadia Shela. 2016. FaktorFaktor Yang Mempengaruhi Status Gizi anak SD Negeri 1 Prongsewu Selatan (Skripsi). Universitas Lampung

[7] Azharkusuma I S, Mulyani E Y, Just ' at I, et al. Status Gizi Berdasarkan Pola Makan Anak Sekolah Dasar di Kecamatan Rajeng Tanggerang. Indonesian Jornal of Human Nutrition 2014 $1(2)$, 138.(http://ijhn.ub.ac.id/index.php/ijhn/ a/rticle/downloas/109/115 Diakes 7 Juli 2018. 19:43)
[8] Bertalina. (2013). Faktor-Faktor Yang Berhubungan Dengan Status Gixi Anak Usia Sekolah (6-12 Tahun). Jurnal Keperawatan, Vol IX, No.1

[9] Dinkes Kab.Bogor. 2015. Profil Kesehatan Kabupaten Bogor. Bogor

[10] Djola, R., 2012. Hubungan Antara Tingkat Pendapatan Keluarga dan Pola Asuh dengan Status Gizi Anak di Desa Bongkudai Kecamatan odayang Barat. Tesis. Manado : Fakultas Kesehatan Masyarakat Universitas am Ratulagi. (http://fkm.unsrat.aac.od/wpcontet/upload/2012/01/RwlovesiDjola.pdf Diakses pada 3 Februari 2018)

[11] Fikawati, Sandra. 2017. Gizi Anak dan Remaja. Depok: Rajawali Pers.

[12] Ghazal Al Moehammad. 2013. FaktorFaktor Yang Berhubungan Dengan Status Gizi Pada Siswa-Siswi 1 SD Juara Medan (Skripsi). Medan : Universitas Sumatera Utara

[13] Hakim Lukman Rizki. 2016. FaktorFaktor Yang Berhubungan Dengan Status Gizi Anak Di Kota Semarang (Skripsi). Semarang: Universitas Negeri Semarang

[14] Kementrian Kesehatan . 2012. Profil Kesehatan Jawa Barat. Jakarta : Kementrian Kesehatan Republik Indonesia.

[15] Kementrian Kesehatan RI. 2011. Direktorat Jendral Bina Gizi dan Kesehatan Ibu Dan Anak Direktorat Bina Gizi. (http://www.gizi.depkes.go.id/wp content/uploads/2011/11/buku-skantropometri-2010 Diakses pada 7 Juli 2018)

[17] Kementrian Kesehatan. 2013. Riset Kesehatan Dasar (RISKESDAS). 
Jakarta : Kementrian Kesehatan Republik Indonesia.

[18] Kementrian Kesehatan. 2014. Pedoman Gizi Seimbang. Jakarta : Kementrian Kesehatan Republik Indonesia.

[19] Kementrian Kesehatan. 2016. Hasil Pemantauan Status Gizi (PSG) dan Penjelasannya. Jakarta : Kementrian Kesehatan Republik Indonesia.

[20] Keputusan Menteri Kesehatan Republik Indonesia Nomor 1995/MENKES/SK/XII/2010, Tentang standar Antropometri Penilaian Status Gizi.

[21] M Ismail. 2013. Pengaruh Tingkat Pendapatan Keluarga, Tingkat Pendidikan Ibu dan Status Pekerjaan Ibu Terhadap Status Gizi Pada Anak Di Kecamatan Darul Makmur Kabupaten Nagan Raya (Skripsi). Meulaboh: Universitas Teuku Umar

[22] Marhamah, Abzeni \& Juwita. 2014. Perilaku Konsumsi Dan Status Gizi Anak Sekolah Dasar Di Kota Serang (Artikel Penelitian). Banten National Geographic Indonesia. 2015. (http://nationalgeographic.co.id Diakses Pada 3 Februari 2018)

[23] Profil Dinas Pendidikan Kabupaten Bogor, http://disdik.bogorkab.go.id/. Diakses 10 Februari 2018.

[24] Pujiati Eny. 2013. Status Gizi Siswa Sekolah Dassar Negeri I Buara Kecamatan Karanganyar Kabupaten Purbalingga (Skripsi). Yogyakarta: Universitas Negeri Yogyakarta.

[25] Puspitasari, DP dkk. 2011. Jurnal Hubungan Antara Status Gizi Dan Faktor Sosiodemografi Dengan Kemampuan Anak Sekolah Dasar Di
Daerah Endemis Gaki. Yogyakarta : Universitas Gajah Mada

[26] Rahmawati Tuti, Marfuah Dewi. 2016. The Description Status of Children at Primary School. Jurnal Kesehatan STIKES PKU Muhammadiyah Surakarta.

[27] Revan. 2014. Faktor-Faktor Yang Bergubungan Dengan Status Gizi SiswaSiswi SD Juara Medan (Skripsi). Medan

[28] Sarwono W, Slamet S, Kartini S, Triyani K. 2010. Pengkajian Status Gizi Studi Epidemiologi Dan penelitian Dirumah Sakit. Balai Penerbit FK-UI 258-263

[29] Sepriantu Vita, dkk. 2015. Status Gizi Anak Kelas III Sekolah Dasar Negeri I Sungaililin. Jurnal Kedokteran dan Kesehatan, Vol 2, No.1

[30] Soetjiningsih. 1995. Tumbuh Kembang Anak. Jakarta : EGC, 37-39.

[31] Suhardjo. 2005. Perencanaan Pangan dan Gizi. Jakarta : Bumi Aksara

[32] Supariasa, I D.dkk. 2002. Penilaian Status Gizi. Jakarta : EGC

[33] Thamaria, Netty. 2017. Penilaian Status Gizi. Jakarta : Kementrian Kesehatan Republik Indonesia.

[34] Unicef. 1998. The State of The World's Chirliden. Oxford University Press. New York

[35] WHO Maternal, newborn, child and adolescent health. New Delhi : World Helath Organization Regional Office for South Asia, 2009. Artikerl diakses pada tanggan 17 Juni 2018 dari http://www.who.int/maternal_child_adolesc ent/topics/child/nutrition/en/

[36] ZADI G. 2016. Peran Keluarga Dalam Satatus Gizi Anak. Journal Human of Nutrition, Vol. 1 No.2 